\title{
Self Defense Mechanism as an Overcoming Tool of Anxiety in the Novel Me Before You by Jojo Moyes
}

\author{
Tery Angela Monica \\ Faculty of Letters, Balikpapan University \\ teryamonica@gmail.com \\ Jepri \\ Faculty of Letters, Balikpapan University \\ jeprinainggolan@gmail.com \\ Ulum Jannah \\ Faculty of Letters, Balikpapan University \\ ulum.jannah@uniba-bpn.ac.id
}

\begin{abstract}
:
This research focuses on the psychology of a character in the novel Me Before You by Jojo Moyes. There are two objectives in this study; 1). To find out the types of anxiety experienced by the character in the novel Me Before You by Jojo Moyes and; 2). To explain how self-defense mechanism works to overcome anxiety in the novel Me Before You by Jojo Moyes. This study uses Sigmund Freud's psychoanalysis theory regarding anxiety and defense mechanism; the methodology employed is qualitative research in which the researcher tried to present the issues descriptively. The main data sources in this study were taken from the form of dialogs, descriptions, and sentences contained in the novel Me Before You by Jojo Moyes. The results of this study, the researcher concluded that there were three types of anxiety experienced by the character in the novel Me Before You by Jojo Moyes, namely neurotic, moral and realistic anxiety. To overcome these anxiety the character uses four types of defense mechanisms namely displacement, reaction formation, rationalization, and sublimation. The most effective type of self defense mechanism to overcome the anxieties that arises in character is rationalization, because an individual where the reality that is lived is all based on logic and rational.
\end{abstract}

Keywords: Psychoanalysis, Sigmund Freud's Theory, Anxiety, Self Defense Mechanism. 


\section{INTRODUCTION}

In this research, the researcher focuses on the psychology of a character in a novel using psychoanalysis theory by Sigmund Freud. Psychoanalysis itself is a study of science that studies human mental development, besides that the reason the researcher use the theory is because there is a link between novels and psychoanalysis, the two things have the same function in life, and both deal with human problems as individual and social beings.

The researcher chose the novel entitled Me Before You by Jojo Moyes as the object in this study because the novel present the story of a character who had physical limitations due to a traffic accident, he could not accept the situation and made him a closed person. The character feels he cannot get happiness in the future with his limited physical condition, on the one hand he feels guilty for being a burden to the people around him.

In the novel Me Before You by Jojo Moyes, the researcher see changes in feelings, perspectives, and ways of thinking that are displayed by characters in an effort to avoid, reduce, and overcome anxiety experienced. The purpose of this research is because the researcher considers it important to know the forms of anxiety that might arise in an individual and character of the novel as representation of real human, beside of that, this study aims to determine the efforts made by individuals to reduce anxiety that arises in the character.

\section{LITERATURE REVIEW}

Psychoanalysis is a scientific discipline put forward by Sigmund Freud. The main goal of this theory is human and psychological and always related to the functions and mental development of humans. In psychoanalysis studied the relationship between memory or observation with development, the connection between observation and adjustment to humans in addition to psychoanalysis presents humans as a formation of instincts and conflicts of personality structure.

Freud as explained in Minderop (2011, p. 21) divides human psychism into three parts, namely: Id as a source of psychic energy, then Ego as an intermediary that balances the demand for Id with the moral standards of the Superego, and the last is a Superego which acts as a barrier to demand and impulses of Id based on the moral standards of the environment and parents.

\section{Anxiety}

Anxiety is a sign of the coming of danger, and a threatening feeling, this can also be said as an unpleasant feeling, worry, and fear of something that is not clear and certain. According to Freud "Anxiety is effective situation which makes unexited and it is followed by physic sensation which can remind someone of dangerous" (as cited in Farokhah, 2015, p. 27-28). The appearance of anxiety depends largely on individual's life experience, and physical condition. The events that have been experienced by someone can influence the mindset and perspective of a person and suppressed emotions such as frustration in a very long time. 
Besides that the emergence of excessive feelings also affects anxiety, one of them is feeling guilty, this feeling is present when someone thinks she/he has done the opposite of conscience and morality in him/her, usually these feelings present other feelings such as unhappy, unworthy, and insecure. Freud distinguishes anxiety into three types, namely: neurotic anxiety, moral anxiety, and realistic anxiety.

\section{Neurotic Anxiety}

Neurotic anxiety is defined as apprehension about an unknown danger. The feeling itself exists in the ego, but it originates from id impulses. People may experience neurotic anxiety in the presence of a teacher, employer, or some other authority figure because they previously experienced unconscious feelings of destruction against one or both parents. During childhood, these feelings of hostility are often accompanied by fear of punishment, and this fear becomes generalized into unconscious neurotic anxiety. (Feist \& Feist, 2008, p. 34)

\section{Moral Anxiety}

This anxiety stems from a conflict between the ego and the superego. This anxiety can arise because failure to be consistent with what they believe is morally right. Moral anxiety is fear of conscience. Moral anxiety also has a basis in reality, in the past the person has been punished for violating moral norms and can be punished again. (Annisa \& Ifdil, 2016, p. 95)

\section{Realistic Anxiety}

Realistic Anxiety is closely related to fear. It is defined as an unpleasant, nonspecific feeling involving a possible danger. For example, we may experience realistic anxiety while driving in heavy, fast-moving traffic in an unfamiliar city, a situation fraught with real, objective danger. However, realistic anxiety is different from fear in that it does not involve a specific fearful object. We would experience fear, for example, if our motor vehicle suddenly began sliding out of control on an icy highway. (Feist \& Feist, 2008, p. 34)

\section{Self Defense Mechanism}

Self-defense mechanism is an individual way to reduce disturbing feelings such as stress, and anxiety, this can be done in a conscious or unconscious state. This is related to behavior changes to reduce discomfort and threaten the individual. In general, the methods used are not solely to change the objective conditions of the threat but change the perception of the conditions faced.

In personality theory, defense mechanisms are characteristics that tend to be strong within each individual. This defense mechanism does not reflect personality in general, but can also affect personality development. The failure of the defense mechanism to fulfill defense functions can result in mental disorders. In defense mechanism, there is an Ego which acts to balance the demands of the Id and the moral standards of Superego on external reality. In addition, defense mechanisms help individuals in carrying out the rejection function of unwanted instinctive impulses, and protect individuals from excessive anxiety. 


\section{Reaction Formation}

Reaction formation is a form of defense mechanism carried out by individuals by replacing impulses that cannot be accepted into acceptable impulses. This happens when a person has an urge to do things that are less pleasant so he will do very well instead, in other words hiding someone's true feelings and motives.

The occurrence of the reaction formation due to original impulses can cause anxiety, to prevent the emergence of anxiety then the Ego suppresses the original impulse then replaces it with the opposite of the original impulse, this is due to the clash of original impulses with moral standards in an individual's environment, to avoid collisions between impulses and moral standard, the individual changes the impulse with behavior that is acceptable to the environment.

\section{Displacement}

Displacement is a form of defense mechanism that makes objects or other people as the target of aggressive impulses that arise. This is because the individual's inability to reach the original impulse target and replace it with a more enabling object which is not a source of frustration.

Individuals with aggressive tendencies will look for a substitute object as a target, and usually chosen as an object is something that does not fight back. It involves a transfer of emotion. However, what is switched is not the source but the object of the emotion. Afraid to display or even to experience certain feelings against whoever has aroused them, the person repress the feelings. Then, when the opportunity arises, he or she transfers that emotion to a safer object and releases it.

\section{Sublimation}

Sublimation is a form of defense mechanism that converts threatening impulses into actions that are beneficial and acceptable to social life. The ego does not always grant impulses from the Id according to their original goals and demands, sometimes if the demands are not right in life and rub against the moral standards of an environment, the Ego will change these impulses into a behavior that can be accepted by these moral standards.

\section{Rationalization}

Rationalization is a form of defense mechanism which gives logical reasons and justifications for the behavior that has been done. Human psychology can accept the reason to make sure it is not in accordance with the wishes and goals.

Rationalization has two objectives, namely to reduce feelings of disappointment when someone fails to achieve his goals, and provide acceptable motives for the behavior that has been done. Rationalization can occur if the real form and motives of an action are not acceptable to the ego. The motive will be replaced by a kind of substitute motive with the purpose of justification. 


\section{RESEARCH METHODOLOGY}

In this study, to analyze novel Me Before You by Jojo Moyes, the researcher used descriptive qualitative research, this is because this study uses an explanation and interpretation of the novel, and tends to use references in the form of theoretical books and references to other literature. The sources of the data in this study are from the novel $M e$ Before You by Jojo Moyes published on 5 January 2012 in the United Kingdom by Penguin Books. This novel has 480 pages.

The purpose of this study is to reveal events, facts, circumstances, phenomena, and variables that occur in the novel Me Before You by Jojo Moyes, in other words this study interprets and describes data relating to the phenomenon of anxiety that occurs in the novel. The data that will be obtained by the researcher in this study are in the form of situation quotations, dialogues, and expressions relating to psychological phenomena.

In this study to analyze the novel Me Before You by Jojo Moyes, the researcher is working through reading of the novel from the beginning to end. To understanding the types of anxiety experienced by the character, the researcher categorizes the types of feelings that arise in the character itself the researcher looking for quotations, descriptions, and dialogues that give an overview of the problem, and to find how the defense mechanisms work to overcome anxiety. After the researcher finds the types of defense mechanism that used to overcome anxiety, the researcher will make an interpretation and write a conclusion.

\section{FINDINGS AND DISCUSSIONS}

\section{Types of Anxiety}

\section{Neurotic Anxiety}

Neurotic anxiety is an anxiety that is unknown and is not recognized by its appearance. This is due to Ego doubts to fulfill Id wishes because there is a fear of punishment that might occur if an instinct is satisfied.

In this study, the researcher found feelings of anger and offended as manifestations and indications of neurotic anxiety that occurred in William Traynor. This is caused by William's concern about something that does not happen and does not necessarily occur when he is faced a situation.

'I don't want to have those bloody pictures staring at me every time I'm stuck in my bed until someone comes and bloody well gets me out again. Okay? Do you think you can get your head around that?' (p. 73-74)

In the excerpt, illustrated When William lay and was helpless in bed, he felt that he was being watched. There is a photo displayed in William's room, in the photo there is himself with his lover and best friend enjoying the holiday. He felt that the photo always staring at him, and he hated it. 
The neurotic anxiety that arises within William, marked by his fear of the photos displayed, this can be seen through the sentence 'I don't have to have those bloody photo staring at me every time ...'. William Traynor was disturbed by the photo displayed in his room, he felt very angry because the photo seemed to be staring at him who was helpless lying on the bed. William seemed to be very weak when he had to wait for someone to come to help him move.

\section{Moral Anxiety}

Moral anxiety arises because of the conflict between the Ego and the Superego. This causes the emergence of guilt in the individual because of Ego failure to follow the moral standards that exist in the environment, and this can be caused by fear of something that is considered contrary to moral beliefs.

In this study, the researcher found guilt is a manifestation of moral anxiety. The emergence of this anxiety was caused by William Traynor's condition which he considered as a burden to others.

'It's not a matter of giving you a chance. I've watched you these six months becoming a whole different person, someone who is only just beginning to see her possibilities. You have no idea how happy that has made me. I don't want you to be tied to me, to my hospital appointments, to the restrictions on my life. I don't want you to miss out on all the things someone else could give you. And, selfishly, I don't want you to look at me one day and feel even the tiniest bit of regret or pity that -' (p. 426)

In the excerpt, illustrated William and Louisa were arguing about his decision to go to Switzerland. Louisa insisted on begging William to give her a chance that there was another way to enjoy and live life despite being someone who was physically imperfect. But, William remained on his mind and tried to make Louisa understand his desires.

The moral anxiety that arises within William marked in sentence 'I don't want you to be tied to me, to my hospital appointments, to the restrictions on my life.' William explained to Louisa that the difficult thing for him was not to accept Louisa and give Louisa a chance with him, but he felt that he had indirectly changed the cheerful Louisa to become someone very different from what he had ever known. William did not want Louisa to be entangled in the gloomy life and he did not want to regret it in the future. He felt guilty for troubling Louisa, he loved Louisa, but he could not if he had to be with Louisa forever and live together. He did not want to make Louisa tied to him, an appointment to see a doctor, and other William's needs. He did not want to limit Louisa's life with all his needs.

\section{Realistic Anxiety}

Moral anxiety is anxiety about threats and dangers from outside the individual such as the environment and certain situations. Moral anxiety can arise because an individual sees a potential danger that can attack and hurt if they are in a certain situations 
In this study, the researcher found feelings of resignation and afraid as manifestations of realistic anxiety. This realistic anxiety arose due to paralysis suffered by William Traynor.

'I can't do this because I can't . . ' He swallowed. 'I can't be man I want to be with you. And that means that this - ' $\mathrm{He}$ looked up into my face '- this just becomes ... another reminder of what am not.' (p. 423)

On the excerpt 1, illustrated Louisa begged William that they are together, he realized that this was not possible because of his limited condition. He could not explain clearly to Louisa, who he knew even if they were united, the relationship was not as beautiful as others imagined.

The realistic anxiety that arises within William marked in sentence 'this just becomes . . . another reminder of what am not.' William felt unable to explain clearly why he could not accept Louisa as part of his life. He only said that he could not be the man he wanted to be with Louisa. William felt he would not be able to be with Louisa because of his limitations. William felt that if he gave the opportunity to Louisa to be with him for a long time, he could not be the perfect man for Louisa. He felt his physical limitations were a barrier to his togetherness and Louisa.

\section{Self Defense Mechanism Work to Overcome Anxiety}

Self-defense mechanism is an individual way to reduce feelings of disturbance which is a factor in the emergence of anxiety. it is intended to protect the Ego from anxiety that arises within an individual. Self-defense mechanism that is used to overcome anxiety can be seen from the changes of feeling, thought, and interpretation.

In this study, the researcher found several types of defense mechanism that works to overcome the anxiety experienced by the character. The researcher found displacement, reaction formation, rationalization, and sublimation as an ego defense tool used by the character to reduce the anxiety that arose. The researcher presented a table containing the types of anxiety that can be overcome by defense mechanism.

\section{Displacement}

Displacement is a form of defense mechanism that diverts unpleasant feelings to other objects that are felt possible. An Individual sometimes feels need to express their feelings but do not want to lead directly to the object, they usually look for substitute objects even though the object is not related to unpleasant feelings. In this study, the researcher found the function of displacement within William which works to relieve neurosis anxiety and realistic anxiety.

a. Displacement Overcoming Neurotic Anxiety

'I don't want to have those bloody pictures staring at me every time I'm stuck in my bed until someone comes and bloody well gets me out again. Okay? Do you think you can get your head around that?' (p. 73-74) 
On the excerpt, the neurotic anxiety that arises within William, marked by his fear of the photos displayed, this can be seen through the sentence 'I don't have to have those bloody photo staring at me every time ...'. To overcome the neurotic anxiety that arises, William uses a displacement, which is by the way he scolds Louisa. He snapped Louisa so that she could understand why he hated the photo so much. Displacement can be seen through the sentence 'Do you think you can get your head around that?' it seen that William tried to make Louisa imagine it if it happened to her with a little yell.

\section{b. Displacement Overcoming Realistic Anxiety}

I saw that he seemed determined not to look anything like the man he had been; he had let his light-brown hair grow into shapeless mess, his stubble crawl across his jaw. (p. 57)

On the excerpt above the realistic anxiety that arises within William marked by William's annoyance at his condition of not being able to do anything, and he felt trapped in a weak and helpless body. To overcome this anxiety, William used displacement as seen in the following sentence 'he had let his light-brown hair grow into shapeless mess, his stubble crawl across his jaw.' to shed all his resentment over his helpless condition, the only way William could do that was to grow hair on his face, not cut his hair, to give the impression that he was very disappointed with his life now.

\section{Reaction Formation}

Reaction formation is a form of defense mechanism carried out by individuals by replacing impulses that cannot be accepted into acceptable impulses. This happens when a person has an urge to do things that are less pleasant so he will do very well instead, in other words hiding his true feelings and motives. In this study, the researcher found a function of the reaction formation within William which worked to relieve neurotic anxiety, moral anxiety, and realistic anxiety.

a. Reaction Formation Overcoming Neurotic Anxiety

'You thought a little drive would be good for me? A breath of fresh air?' (p. 50)

On the excerpt illustrated Louisa was very happy to invite William to speak and she asked why William did not want to enjoy himself by going around his residence. However, William considers that it is useless for him. The neurotic anxiety that arises within William that being going around his residence is useless. To overcome this anxiety, William used reaction formation as seen in the following sentence 'You thought a little drive would be good for me?' William felt a little offended when Louisa asked him why he didn't spend time outside the house. However, he turned the question over to Louisa with a calm reaction, he asked Louisa so that she understood that he thought it meant nothing to him.

b. Reaction Formation Overcoming Moral Anxiety

'What's up with you?' 
'What do you mean?'

'You're quite.'

'You said you wanted me to be quiet.'

'Not this quiet. It alarms me.' (p.117)

On the excerpt 3 the moral anxiety that arises within William marked in sentence 'Not this quiet. It alarms me.' he started to worry when Louisa became very quiet when they were together. To overcome this anxiety, William used reaction formation as seen in the following sentence 'What's up with you?' although William really hated it when Louisa talked too much, he felt guilty when he made Louisa become very quiet, so from that William tried to find out what was wrong with Louisa that made him a very introverted person.

c. Reaction Formation Overcoming Realistic Anxiety

When Patrick spoke again, there was a faint air of martyrdom in his tone." 'It's just research that I thought might be helpful. But I'll say no more about it.' Will looked up and smiled, his face blank, polite. 'I'll certainly bear it in mind.' (p. 232)

On the excerpt above the realistic anxiety that arises within William when he heard the words spoken by Patrick, he knew that the condition of his body would not heal and improve even though he underwent various processes of therapy and treatment. To overcome this anxiety, William used reaction formation as seen in the following sentence 'I'll certainly bear it in mind.' although a little offended and knew that he had no hope of recovery and normalcy, William still accepted advice and behaved politely to Patrick.

\section{Rationalization}

Rationalization is a defense mechanism that aims to reduce discomfort when an individual fails to achieve something by giving acceptable motives for the behavior that has been done by an individual. In this study, the researcher found the function of rationalization within William Traynor namely working to overcome Neurotic anxiety, moral anxiety and realistic anxiety.

a. Rationalization Overcoming Neurotic Anxiety

'But it does define me, Clark. You don't know me, not really. You never saw me before this thing. I love my life, Clark. I really love it. ...' (p. 426)

On the excerpt 1 , the neurotic anxiety that arises within William marked in sentence '...You don't know me, not really.' William would never be able to understand himself, his life, and his desires, including Louisa. Even though Louisa cared for him wholeheartedly for William it was not guaranteed if Louisa understood him completely. To overcome this anxiety, William used Rationalization as seen in the following 
sentence 'You never saw me before this thing.' William make natural that if Louisa attempted to motivate him to live his life and enjoy every moment that is considered valuable even though he is not a perfect person, because Louisa never knew and knew William's life before he became who he is today. He loved his life and all his activities.

b. Rationalization Overcoming Moral Anxiety

'It's not a matter of giving you a chance. I've watched you these six months becoming a whole different person, someone who is only just beginning to see her possibilities. You have no idea how happy that has made me. I don't want you to be tied to me, to my hospital appointments, to the restrictions on my life. I don't want you to miss out on all the things someone else could give you. And, selfishly, I don't want you to look at me one day and feel even the tiniest bit of regret or pity that -' (p. 426)

On the excerpt 3, the moral anxiety that arises within William marked in sentence ' $I$ don't want you to be tied to me, to my hospital appointments, to the restrictions on my life.' William felt guilty for troubling Louisa, he loved Louisa, but he could not if he had to be with Louisa forever and live together. He did not want to make Louisa tied to him, an appointment to see a doctor, and other William's needs. He did not want to limit Louisa's life with all his needs. To overcome this anxiety, William used rationalization as seen in the following sentence 'I don't want you to miss out on all the things someone else could give you.' William realized with his limited condition, he would not be able to give everything that could make Louisa happy, for him Louisa deserved to enjoy her life to the fullest without having to be attached to William, and Louisa could find someone else who could give her everything. William might feel selfish about his decision, but aside from that he didn't want to make Louisa waste her life only for someone as helpless as him.

c. Rationalization Overcoming Realistic Anxiety

'It's not enough for me. This - my world - even you in it. And believe me, Clark, my whole life has changed for better since you came. But it's not enough for me. It's not the life I want.' (p. 425)

On the excerpt 6 , the realistic anxiety that arises within William marked in sentence 'It's not enough for me. This - my world - even you in it.' for William Louisa's loyalty and sincerity to stay with him forever would not be enough to change the way he looked at the life he wanted. Although Louisa was present in his life for him, his life would still not be perfect without being physically perfect. To overcome this anxiety, William used rationalization as seen in the following sentence 'And believe me, Clark, my whole life has changed for better since you came. But it's not enough for me. It's not the life I want.' he acknowledged Louisa's presence in his life, making his life more colorful. He 
felt that being a different person from Louisa's ethics was in his life, but that was not enough for him because it was not accompanied by perfect physicality.

\section{Sublimation}

Sublimation is a defense mechanism that converts uncomfortable feelings into forms of action that are beneficial to the environment and socially. In this study, the researcher found the function of sublimation in William which worked to relieve moral anxiety.

a. Sublimation Overcoming Moral Anxiety

'Louisa, nothing was ever going to change my mind. I promised my parents six months, and that's what I've given them. You have made the time more precious than you can imagine. You stopped it being an endurance test -' (p. 428429)

On the excerpt above the moral anxiety that arises within William when he must release all the pain and suffering, but he did not want to hurt and disappoint the people around him, especially his parents To overcome this anxiety, William used sublimation as seen in the following sentence 'I promised my parents six months, and that's what I've given them.' as a redemption of his guilt had made the decision that made his parents sad, William gave his parents time for six months before he went to Switzerland. He knew that his decision was the wrong one, but William could not endure longer with his weak body, he was not strong if he had to continue to depend on drugs and medical care if he at times got worse.

\section{CONCLUSION}

Based on the results of the study, the researcher concluded that rationalization is the most effective type of defense mechanism to deal with realistic anxiety; this is because rationalization works based on the reality experienced by the individual, where the individual tries to rationalize the reality being faced. Besides that, rationalization works to overcome neurotic anxiety, this anxiety arises in an individual based on disturbing thoughts and without clear reason, to reduce the appearance of neurotic anxiety, an individuals will use rationalization by trying to rationalize things that become neurotic anxiety factors, so that irrational thoughts that try taking over can be prevented. Rationalization works to overcome moral anxiety, when an individual does what he thinks has violated the norms and values of goodness that he believes in, and then feelings of guilt arise. This feeling is a manifestation of moral anxiety, and therefore to reduce the feelings of guilt that arise, an individual uses rationalization as a self defense mechanism, the way is to make a mistake that has been done is fine.

Besides rationalization, the defense mechanism used to overcome realistic anxiety is displacement. when an individual faces a difficult situation there arises a feeling of fear and resignation as a form of realistic anxiety, to overcome the fear that arises due to a situation, usually an individual uses objects, other people, even parts of himself as targets for the 
release of these feelings, efforts to vent this is called displacement, where an individual is looking for a substitute object to release the feelings that burden him. In addition to realistic anxiety, displacement is used to treat neurotic anxiety. Someone who experiences realistic anxiety is very irritable and feels offended, this is because they are controlled by irrational thoughts. To reduce neurotic anxiety, an individual tries to find a substitute object that is represented by an overwhelming anger.

Neurotic anxiety manifested by feelings anger and offended can be overcome by reaction formation as a defense mechanism. An individual who is reluctant to display his feelings of anger towards others will use reaction formation. This can generally be known when an individual is very angry they will react very well to others to cover up their original feelings. Likewise with realistic anxiety which is manifested by feelings of fear and resignation. An individual who experiences realistic anxiety who uses reaction formation as a defense mechanism will react like tough and very patient or strong in facing something they fear. Moral anxiety can also be overcome by reaction formation, as it is known that moral anxiety is manifested by guilt for violating a norm of goodness that is believed to be an individual, to overcome moral anxiety someone who uses reaction formation as a defense mechanism will act as if they are very obedient to a rule for cover up their guilt.

Sublimation is used by an individual who has moral anxiety. To reduce guilty feeling after violating a norm or rule that applies, usually an individual will do something good as atonement for the mistakes their have done.

\section{References}

Annisa, Dona Fitri. \& Ifdil. (2016). Konsep Kecemasan (Anxiety) pada Lanjut Usia (Lansia). KONSELOR 5(2).

Brenner, MD., Charles. (1973). An Elementary Textbook of Psychoanalysis. New York: International Universities Press.

Budd, Susan., \& Rusbridger, Richard (Eds.). (2005). Introducing Psychoanalysis Essential Themes and Topics (Online). Retrieved June 19, 2019, From https://books.google.co.id/books?id=wmwMOiQWm4C\&pg=PA105\&dq=susan+bud

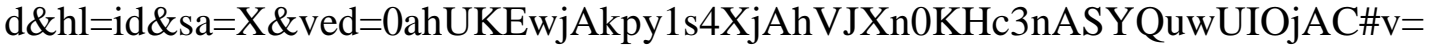
onepage $\& \mathrm{q}=$ susan $\% 20 \mathrm{budd} \& \mathrm{f}=$ false

Caprara, Gian Vittorio., \& Corvone, Daniel. (2000). Personality Determinants, Dynamics, and Potentials (Online). Retrieved June 13, 2019, From https://books.google.co.id/books?id=Qf6BsHA5SoC\&pg=PA15\&dq=personality+str ucture \&hl=en\&sa=X\&ved=0ahUKEwjPj8GazPXiAhUCnawKHXrEAx04FBDoAQg _MAQ\#v=onepage\&q\&f=false

Cervone, Daniel., \& Pervin, Lawrance A. (2013). Personality Theory and Research. USA: John Wiley \& Sons, Inc.

Conte, Hope R., \& Plutchik, Robert (Eds.). (1995). Ego Defenses Theory and Measurement (Online). $\quad$ Retrieved June 19, 2019, From 
Prologue: Journal on Language and Literature Vol.6 No.1 (2020)

https://books.google.co.id/books?id=YiRhdsC8L7IC\&printsec=frontcover\&dq=ego+ defenses\&hl=id\&sa=X\&ved=0ahUKEwiBvoTKtIXjAhVbnI8KHevkAZMQuwUILT

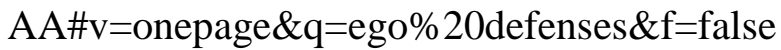

Cramer, Phebe. (2006). Protecting The Self Defense Mechanism in Action (Online). $\begin{array}{llll}\text { Retrieved June } & \text { 18, 2019, From }\end{array}$ https://books.google.co.id/books?id=FNsmzylLagC\&printsec=frontcover \&dq=self $+\mathrm{d}$ efense+mechanism\&hl=en\&sa=X\&ved=0ahUKEwi2s7nR_fXiAhUZXSsKHU20B2g Q6AEIKjAA\#v=onepage \&q=self\%20defense $\% 20$ mechanism $\& \mathrm{f}=$ false

Denzin, Norman K., \& Lincoln, Yovnna S. (2018). The SAGE Handbook of Qualitative Research. California: SAGE Publication, Inc.

Dryden, Windy., \& Reeves, Andrew (Eds.). (2014). Handbook of Individual Therapy (Online). $\quad$ Retrieved $\quad$ May 21, 2019, From https://books.google.co.id/books?id=Iu6GAwAAQBAJ\&printsec=frontcover\&source =gbs_atb\#v=onepage $\& q \& \mathrm{f}=$ false

Farokhah, Fiqih Aisyatul. (2015). Anxiety Suffered by Elizabeth Holland in Anna Godbersen's Splendor Published Thesis. Maulana Malik Ibrahim State Islamic University of Malang, Malang, Indonesia.

Fuad, Khairul. (2014). Jilly's Defense Mechanism as Seen in Phyllis A. Whitney's The Singing Stones Unpublished Thesis. State Islamic University Sunan Kalijaga, Yogyakarta, Indonesia.

Harding, Celia (Ed.). (2019). Dissecting The Superego Moralities Under The Psychoanalytic Microscope (Online). Retrieved June 18, 2019, From https://books.google.co.id/books?id=4gB-

DwAAQBAJ\&pg=PT5\&dq=celia+harding\&hl=id\&sa=X\&ved=0ahUKEwjPqK7msI

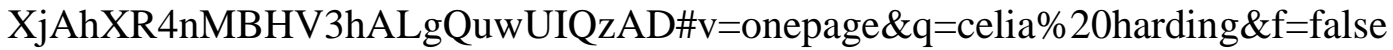
Minderop, Albertine. (2011). Psikologi Sastra. Jakarta: Yayasan Pustaka Obor Indonesia Moyes, Jojo. (2012). Me Before You. Britain: Penguin Books.Hentschel 